\title{
MIGRATION IN THE CONTEXT OF THE PRINCIPLES OF TERRORISM
}

\author{
Marián Mesároš ${ }^{1}$
}

\begin{abstract}
The content and subject of this paper, that is Migration in the context of the principles of terrorism, is in close cerrespondence with the scientific project of the Ministry of Interior of the Slovak Republic called Creating and testing presentations of projects preventing illegal criminality. Migration is a problem all over the world and represents a huge financial, but above all a social, burden for economically developed countries. In early 2020, the problem partially receded as a result of the global pandemic, but the problem still exists and is waiting to be solved. The same problem is being faced not only by the EU countries, but also by the USA on the border with Mexico. However, populist manifestations of the new USA government will bring another problem of huge dimensions. EU countries must quickly find a common solution on how to protect countries in the northern Mediterranean Sea and avoid declarations of legacy linked to the past. A new image is being gained by terrorism penetrating the cyberspace, and migrants getting ready to do so represent an instrument in the hands of organizations from the Arabian world. After world pandemics, EU countries will begin to recover from economic problems, and migrants will gain new strength because they will already have information about how to obtain shelter benefits in individual countries. They primarily want to go to economically developed countries, so the happiness of post-socialist countries is that they are not among the dream countries of economic migrants. There is one rule that will always be true, and namely, the easy money will wean the native population off their work habits, and subsequently whatever they get without work in their home country they can get in any other EU country. The research methods used to write this article were: analysis, synthesis of available information, reports, scientific articles on the topic, and subsequent deduction to determine conclusions.
\end{abstract}

Key words: migration, society, globalization, safety, terorism, integration, polotical solutions, cyberspace.

JEL Classification: O15, F22, F52, D24

\section{Introduction}

Recently, people not only in the EU, but all over the world, have been traumatized by the word MIGRATION. While in previous centuries migrations represented progress and help for developing countries, today migrations are a fear for developed countries.

Since certain countries of the world are today traumatized by the Coronavirus pandemic, the migration wave seems to have lost its significance. The media rarely reports on the rescue of migrants by non-governmental organizations, as in the case of the ship OCEAN VIKING off the coast of Libya, which rescued 260 people on March 4, 2021. One can only wonder why the migrants were not returned to Libya, but overloaded the already overcrowded migration camps in Italy, France, or other countries on the northern Mediterranean coast.

The solution to the migration crisis is quietly resonating within EU governments and has more than once led to the tearing up of governments. It is not the purpose of this article to pass judgment on who should accept migrants or how many migrants individual EU countries should accept. Anyway, those setting out on the long journey from Africa have already decided for their dream country. The EU bodies have not yet been able to find consensus on common criteria for establishing admission quotas for each member state. Some developed EU countries mistakenly believe that the post-socialist countries that were transformed into EU structures in the early 1990s can solve this problem. However, one fact is forgotten, namely the post-socialist countries were not socialist before the World War II, so the basics of building a free market economy remained and lasted 40 years during the construction the socialism.

Modern migrations represent a different phenomenon, namely individual people in numbers of several thousand.

\footnotetext{
Corresponding author:

${ }^{1}$ University of Security Management in Košice, Slovakia.

E-mail: vsbm@vsbm.sk

ORCID: https://orcid.org/0000-0002-4826-0130
} 


\section{Migration}

\subsection{Migration and its origins and possible results}

Many recognized sources claim that there are now about one billion migrants in the world. Based on the estimated world population of 7 million people, this is an alarming number, as one in every 7 th inhabitants of the Earth is a migrant.

Currently about 250 million people are trying to migrate, mostly from developing countries or from places threatened by military conflicts. Many migrants are represented by economic ones who seek a new place of residence, usually in an illegal way, that is, with the help of human traffickers (modern business). The remaining 750 million of migrants are moving towards their dream country, within the internal affairs of countries, primarily in Asia and Africa (Mesároš, Lošonczi, 2019). The European Union, despite having about 500 million inhabitants, is too small to handle so many migrants, especially if they are of different nationalities, races or religions.

The most serious resource of migration is represented by the globalization of the world after the end of the two world wars and contributes, in addition to prosperity, to the degradation of traditions primarily of developing countries, humiliating their religion. The security and legal aspects of globalization have affected entire nations for more than 100 years. Already at birth, humans engage in a struggle for survival, which they repeatedly face, however, without trying to regulate it. Subsequently, such despondency cools religious and/or national sentiments and escalates into actions frighteningly called terrorism. The European Union, which is a modern empire of European states, must confront this problem and consistently analyze and seek promising, perhaps unacceptable, solutions.

Based on data from recent studies, it is a well-known fact that the natural decline of the population in the EU member states has decreased greatly in recent years. This means that more investment in social and health services for the elderly is needed in the near future, which should have a positive impact on the EU economy. One of the UN scripts on maintaining the stabile growth of the EU population refers to the fact the EU needs more than 47 million migrants within the years 2000-2050. From this point of view, migration can be positive for the labor market. On the other hand, EU citizens are very afraid of an overflow of labor from Central and Eastern Europe. That is why the Parliamentary Assembly of the Council of Europe has proposed the creation of a European Migration Monitoring Center, focusing on detailed monitoring of all migration and integration policies and the effectiveness of measures taken. According to the November 2002 Eurobarometer, a majority of EU citizens agreed with EU enlargement, whereas $22 \%$ of citizens were against it, while the percentage of countries expected to be affected by migration was even higher, i.e. Austria 32\%, Sweden 28\%, France, Germany and Finland 27\%.

From a macroeconomic point of view, migration should have many positive aspects, such as an increase in the productive labor force, more taxpayers, more subsidies to social funds, and the acquisition of new skills by young people. All this should also have a positive effect on the economic efficiency of a future multicultural Europe. This is why integration measures should ensure that all migrants have suitable conditions and participate fully in the life of a particular country.

Although the content of this article is not intended to solve the world's problem, it attempts to point to its current state as alarming and to suggest possible solutions. The author of this article has long been concerned with security in general and therefore considers the current state of the world an alarming and serious warning to future generations.

\subsection{Migration and its short history}

One of the most frequently used words at the present time is "SAFETY". The word refers to the safety of a person, a group of people, a nation, a nationality, a country, or a group of people of the same religion. Fear for one's safety usually stems from the fact that the environment is insufficiently protected. Attacks on social and/or personal security have become an important strategy for achieving not only personal but also group interests. The globalization of the world economy and the desire for wealth lead to military conflicts, often expressed in religious and/or racial forms of fanaticism. It is noteworthy that countries with no pressing need to solve such problems use third countries both to present themselves as "peacemakers" and to build and reconstruct what has been destroyed by military conflicts. It is not necessary to be familiar with this fact as much as Eric Margolis ${ }^{1}$ to understand that designating possible enemies as allies of Al-Qaeda represents a way of how to withold their political and human rights and make such enemies illegal.

A similar concept was created by Israel, namely the concept directed against the Palestinians. However, it has yet to be confirmed whether al-Qaeda, so glorified and at the same time condemned, was really that powerful, or whether it was just a creation of the Western world, representing a kind of bridge to allow unimpeded entry with UN sanction into this country full of crudeoil and enormous mineral resources.

\footnotetext{
${ }^{1}$ Eric Margolis - writer and foreign editor of Sun National Media, Canada.
} 
Another example of how propaganda can become a reality is in Egypt. The majority of the population of this country elected their government voluntarily, namely in favor of stabilizing political and social life. Those brave men who chose to take on this burden were immediately declared terrorists, and the country, which was trying to stabilize itself, was again destabilized. One should not look for the cause of such a problem, because a similar situation, though more bloody, can be observed both in Syria and not far from the borders of Slovakia, specifically in Ukraine.

\subsection{Migrants - protected species}

The designation of migrants as a protected species expresses the situation not only aptly, but also frighteningly. However, is characterizing the migration (in the future being compared to the migration period - the end of the 4th up to the beginning of the 7th century) it is necessary to mention the fact of the existence of the present humanity, namely also as a result of migration.

The appearance of the then Africa was absolutely different, i.e. living conditions were excellent, that is why the designation SPECIES is suitable and apt (Mesároš, 2012). Humans came to Europe via Asia 40,000 years ago, and began settling in the Americas 20,000 years ago. Such a demanding and complex mission reached its pinnacle thanks to the technological revolution in the 18 th and 20 th centuries.

It seems that the present humankind ( 7 billion) will quietly live and reproduce. But it was not so in the past, and it will not be so in the future.

\subsection{Reasons of human migration}

With the growth of relative prosperity, man began to separate labor and personal property. The rich began to exploit the poor, which more than once led to various riots and military conflicts. Modern political scientists confuse and erroneously compare migration from Europe to America (19th and 20th centuries) with current migration (which began in 2015). The migrants who came to America 80,000 years ago were a blessing to the continent and a driving force behind subsequent development. Many of the migrants stayed on the new continent, but many of them returned and brought with them not only money, but also invaluable knowledge of science and technology. So those who returned tried to give back to their countries what they had lost by the departure of their people to the New World.

It is very important to ask the following questions: For what reason do so many migrants leave their home countries? Who caused or contributed to this situation? The answer is that there cannot be only one culprit, since, for example, if one wants to cause any body to move, the first impulse is necessary, which may be accidental or intentional, but it is followed by other impulses.

All of us involved in foreign security policy understand that the goal of such momentum at this time is economic globalization, in whatever form it takes. The desire for profit knows no boundaries and is characterized by the search for weaknesses of opponents and their intimidation, even in a political way. The pursuit of power by individual political parties, mostly in the Third World, is a breeding ground for world powers, which they can also properly exploit. Forms of abuse of unstable states have a long tradition and are supported by the desire for power and personal gain.

Similar, sometimes even funny, events took place in the former Czechoslovakia, precisely as a result of the regime of that time. It was unprecedentedly flattering to government representatives in the 1950s, for example, when shoemakers from the USSR (Union of Soviet Socialist Republics) came to gain new experience in the footwear industry. In the Czech town Gottwaldow (now Zlín) the Soviet shoemakers could see a huge banner saying: "Soviet shoe industry example to us". However, the Soviets politely asked the management of the Czech industry to remove the banner.

Why does this story blend in with the topic of migration? The American world "policeman" repeatedly looking for suitable places to build up his capital, turns his attention to countries willing to obey him. Methods of attracting attention take different forms; the author of this article does not want, for example, to condemn the nuclear weapons tests in North Korea, but it is necessary to emphasize that the UN has not yet set a date for a meeting in favor of solving the serious problem, and the American aircraft carrier has already sailed to the coast of the Korean Peninsula (Mesároš, 2018).

\section{Migrations in history of Slovakia}

Although migration has always been a part of human life, it became more intense in the period since the 17 th century, namely due to technological progress and maritime discoveries. European countries were acquiring colonies and therefore deliberately supporting the settlement of their inhabitants in the new territories. It is estimated that approximately 65 million people from Europe moved to North America and South America between the seventeenth century and World War II and in international migration waves. 17 million people decided to go to Africa and Australia. Two world military conflicts in the 20th century further intensified global migration. America and Australia gradually became immigration countries, while Europe became a region of migration. 
This has greatly influenced the modern state of Europe. European states are characterized not only by a high proportion of different ethnic and national minorities, but also by a large number of migrants who gradually arrived in certain countries after World War II. This has turned Europe into a mosaic of many cultures living together in one large unit.

In the past, as in the present, people left their homeland as a result of war, starvation, or persecution. Within the involuntary migration an important milestone is represented by the year 1951 when Convention relating to the status of refugees (the 1951 Refugee Convention / the Geneva Convention of 28 July 1951) was adopted in Geneve. The Convention defines the concept of a refugee, the form of legal protection, other forms of assistance, and the social rights that refugees are to receive from the signatory countries of the Convention. The basic rule of the Convention is that refugees should not be returned to their country if they face persecution there. The Convention also defines the responsibilities of refugees toward their host countries and specifies that certain categories of people, such as war criminals, cannot be granted refugee status. The 1951 Convention relating to the status of refugees was more or less limited to the protection of the European refugees after the WW II. As the 1967 Protocol broadened its applicability and removed geographical and temporal limitations, it became a universal instrument as the problem of human displacement spread throughout the world.

Just as European countries are related to the phenomenon of migration, the same can be said of present-day Slovakia, which is also diverse as a result of migration waves on its territory. Slovakia's history is influenced not only by Slovak history, but also by other cultures gradually coming to its territory. Settlement of the territory of Slovakia lasted about 15 centuries, and the Slovaks as a modern nation can be talked about as early as the end of the 19th century. Many other tribes and ethnic groups also formed the population of the territory of present-day Slovakia, for example, Hungarian tribes came to Europe around the 10th century, when they settled in the eastern part of the island of Rye island (Žitný ostrov).

Further, the population of Slovakia was affected by the attacks of the Ottomans (Ottoman Empire), specifically for several centuries. The attacks caused the migration of populations from the southern sides of Europe, such as present-day Hungary, Romania, and Croatia to the territory of the present Slovakia. Within the $12^{\text {th }}$ and $13^{\text {th }}$ Romanies strated to come to Europe. They settled in the territory of the Hungarian monarchy because, unlike in Western European countries where they were persecuted, the Hungarians tolerated them. Since the Hungarian monarchy was neighboring the Ottoman Empire and waging wars with it, the monarchy needed craftsmen to equip its armies. Many Romanies were blacksmiths and therefore needed a monarchy. During the reign of Maria Theresia and Joseph II. several measures were taken focusing on settling Romanies and their assimilation.

Since the $14^{\text {th }}$ and $17^{\text {th }}$ centuries the territorry of the present Slovakia started to be settled by the Vlachs (in Slovak: Valasi) who brought with them a pastoral culture and settled mostly in the mountainous regions of Slovakia. They brought many elements with them nowdays regarded as symbols of Slovakia, e.g. valaška (sheperd's axe having a long handle), bryndza (sheep cheese), žinčica (whey of the sheep milk).

The Germans, who arrived in several waves and were mainly engaged in crafts and mining, also had an important influence on the formation of the Slovak population.

Nor should we forget the influence of several waves of Slovaks from what is now Slovakia to the so-called "Lowlands" (the northern part of former Yugoslavia), where a small population of Slovaks remained living after the wars with the Ottoman Empire ended.

Later during the $20^{\text {th }}$ century many Slovaks left Slovakia for the USA and countries of South America. This form of migration was motivated by money, i.e., people left to make money, but there were also those who were persecuted (Jews) or left Slovakia for fear of the Nazi and then Communist regimes.

The modern Slovak population has been shaped by many factors throughout its history, i.e., what is considered Slovak culture has absorbed elements of many cultures and ethnic groups that existed on Slovak territory (Mesároš, Lošonczi, 2019).

\section{Migrants between the period 2016-2020}

Based on relevant studies, it can be argued that $90 \%$ of migrants are people under middle age. They are not ashamed to take small children and old people (even 100 -year-olds) with them. This is one of the calculations of the Arabs, namely to arouse the compassion of Europeans. To a certain extent they succeeded. However, a year later it turned out that $90 \%$ of migrants (about 1 million) in Germany did not have any labor skills, because they lived very well in their home country. They have no relatives in Europe, they are believers, and they are unable to respect the laws and rules of the countries where they wanted to go (Germany, Sweden, Great Britain).

Preliminary estimation of German employment specialists says the majority of migrants will only be able to be employed as early as in 10 years. Within 2017 other 2 million migrants have come, however there is not a specialist that would estimate costs of tax payers for covering the life of migrants during the 10 years. But politics and the election of German representatives for the next period are more important than fear of the immediate future. 
It is necessary to state the author of this paper is no racist or unwilling to improve living conditions of migrants, however being a safety analyst he is a realist, pragmatist and proposes aiding migrants in their home countries, namely within solidarity and under the auspices of the UN.

\subsection{Integration of migrants into society}

International migration represents statements including a large amount of theses, opinions and directions, generous and limited approaches (Doina Popescu Ljungholm, 2014).

Migration policy is closely related to the integration of migrants into society. The result of this process should provide them with the same chances and prospects in life as the majority society. Integration policy is a set of tools that should facilitate the successful integration of migrants into life in the host countries.

The importance of integrating migrants into society is being stressed, as unsuccessful integrating will result in their staying at the edge of society. We can say that they are marginalized (they are many in the lower social strata) and segregated (they live in isolated communities). Failure to integrate will make it difficult for them to find a better-paying job and/or obtain higher education, and their chances of success will be greatly reduced if they fail to learn the language of the host country. Nowdays, they are frequently discriminated and abused as cheap labour. Living at the edge of society forces them to solve the situation contrary to law.

The economic component of integration and the need for migrants to find work in the host country in order to become economically independent and selfsufficient are often emphasized. Migration, however, concerns every spehere of life. For migrants, not only jobs and salaries are important, but also the place of residence, educational opportunities for them and their children, access to healthcare and social services.

Except the economic integration it is political, cultural and citizenship integrations that seem to be very important. Integration of migrants into these spheres means for them the opportunity to be part of society (civic associations, organizations, communities), to participate in political (the right to vote and to be elected) and cultural life of society (to be able to preserve their cultural characteristics). Through the successful integration of migrants into these spheres of life, they can feel that they are an appropriate part of society in the host country. Until this happens, migrants will often have a sense of inferiority and uprootedness, a sense of belonging to neither their home country nor their host country. One can meet such a problem not only in case of the so-called first generation of migrants, but also with the next generations being born in their host country, i.e. already its citizens.

Therefore, the goal of integration policies should be represented by practical issues concerning the lives of migrants, as well as efforts to create a general awareness that migrants are an adequate part of society. There is usually no need to create autonomous policies and independent measures focused on migrants, it is enough to keep in mind that within existing policies there are special groups, such as migrants, whose status and needs may be different. Such an approach to migrants within the public policies is called integration mainstreaming (Mesároš, Lošonczi, 2019).

\subsection{The present state of the migration crisis}

The present migration is the result of illegal human trafficking. Most of the victims of this crime (modernday slavery) are between the ages of 16 and 30, and predominantly women from poor socio-economic backgrounds. Such people live in very poor conditions, they have debts and/or do not have a permanent job. The human trafficking predominates in favour of sexual slavery - approximately $53 \%$ of all the cases. This form of trafficking is followed by exploitation in connection with forced labor - about $40 \%$ of all the cases.

The activities associated with this type of illegal migration concern ordinary people only partially. It concerns specific people and their families. The impact on internal order and security is obvious, but the residents of destination countries are only minimally interested. Anyway, they do not perceive the problem of illegal migration in connection with human trafficking the way they perceive illegal migration and people from third countries.

Nowadays, the most numerous cases of illegal migration in Europe, the most perceived by inhabitants living there, are connected to illegal human smuggling over the frontiers of the European countries. The illegal migrants go across the majority of these countries, holiday resorts or places refering to the old continent. They have a direct impact on security and internal order in these countries, i.e., they pose a great security risk (Mesároš, 2010).

The number of people leaving their home countries to live in other places continues to grow. Actual estimations of the UNO are as follows: more than 213 million migrants in 2010, an increase of 15 million in 2005. Migrants represent not only highly qualified workers, but also people trying to unify with their family. Migrants who have decided for one of the European countries as their dream country are represented by approximately $32 \%$ of the worldwide migration process.

From an EU perspective, current migration has different characteristics compared to the first migration 
wave. One characteristic feature is the abolition of border checks between participating countries. This represents a profit only for the third country citizens. Growing migrant pressure at the EU's external borders has gradually led to the fact that individual states cannot change the instruments of national legislation, and thus cannot influence key aspects of migrants' entry into and stay in dream countries. Illegal migration in EU countries is difficult to manage with traditional political instruments.

Reasons for migrations necessitate asking the following questions:

- Why are mass migrations appearing just now?

- What are the reasons people decide to leave their home countries?

- Who organizes and conducts mass migrations?

- If anybody conducts and organizes the migration situation, why do they do so?

At the present time, also thanks to the EU measures and calming down the war situation in Syria, the number of migrants has substantionally decreased, namely by as much as $50 \%$, which means that 2018 meant a partial calming of the situation in Europe. However, another problem arises in relation to the security of refugee camps in France, Germany,
Italy and Turkey, which represents another phase of solving migrations.

Figure 1 shows the migration routes before 2015 and also partially after taking the EU measures in 2016 (Štatistiky MV SR).

Not every country is accomodating, even if it is just a transit land. For example, Hungary built a fence on its border with Serbia and tightened laws on illegal entry and shelter. This affected the route that many refugees had used before. So migrants try every possible way to get to the country of their dreams, and they don't want to ask for shelter until they are there, and so they are always looking for new routes for refugees.

Figure 2 shows the original refugee routes through Hungary in black. The routes used after the closure of the Hungarian borders are shown in red. After the closure of the borders and the construction of the fence with Serbia, refugees began to use the route through Croatia and Slovenia. The route less used by refugees is the one across the Black Sea.

The refugee situation is most complicated for countries such as Greece, Macedonia and Italy, which are the first countries in contact with refugees in Europe. The pressure of these countries concerns securing safety of citizens and protection of

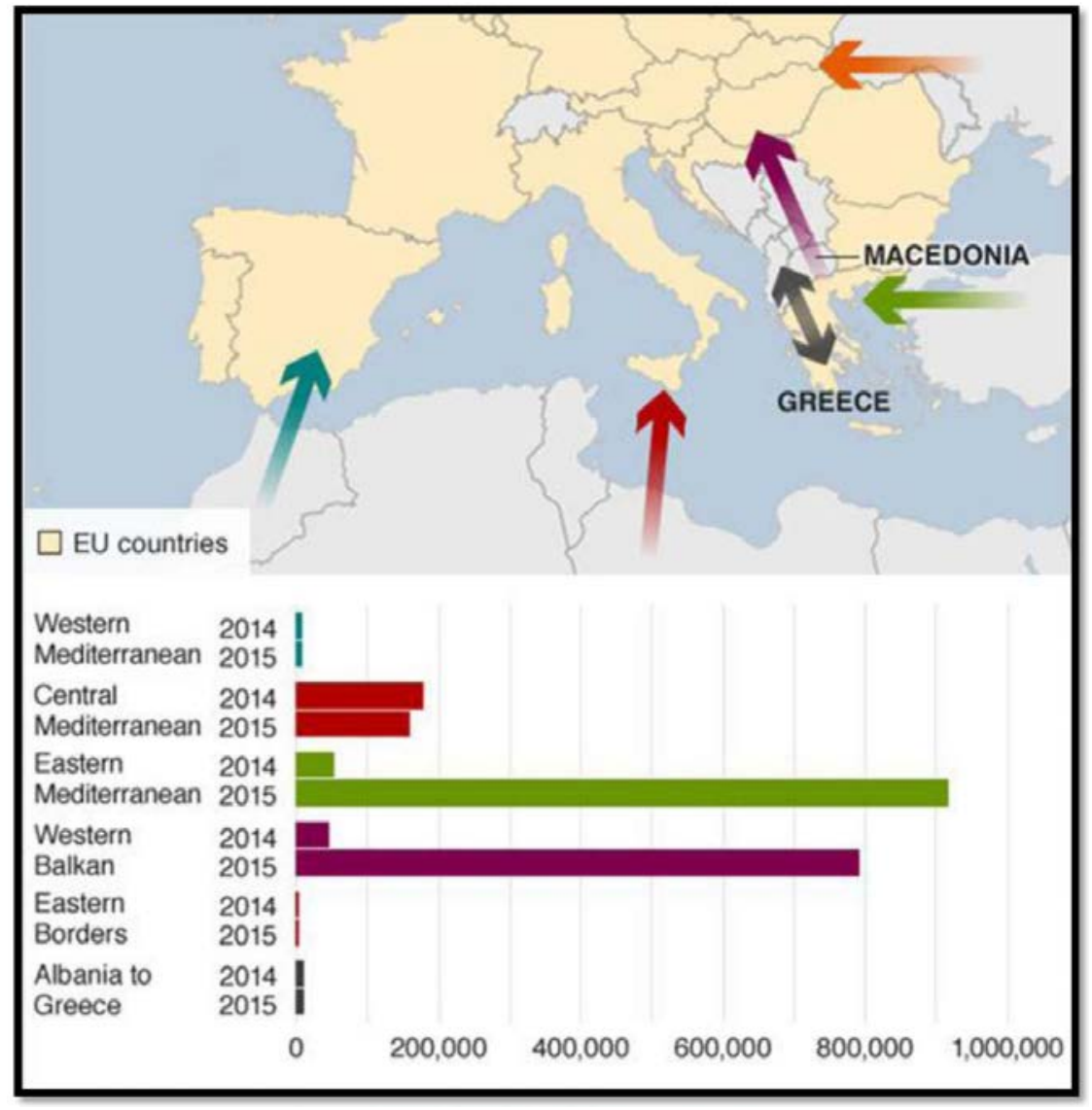

Figure 1. Refugee routes

Source: (Štatistiky MV SR) 


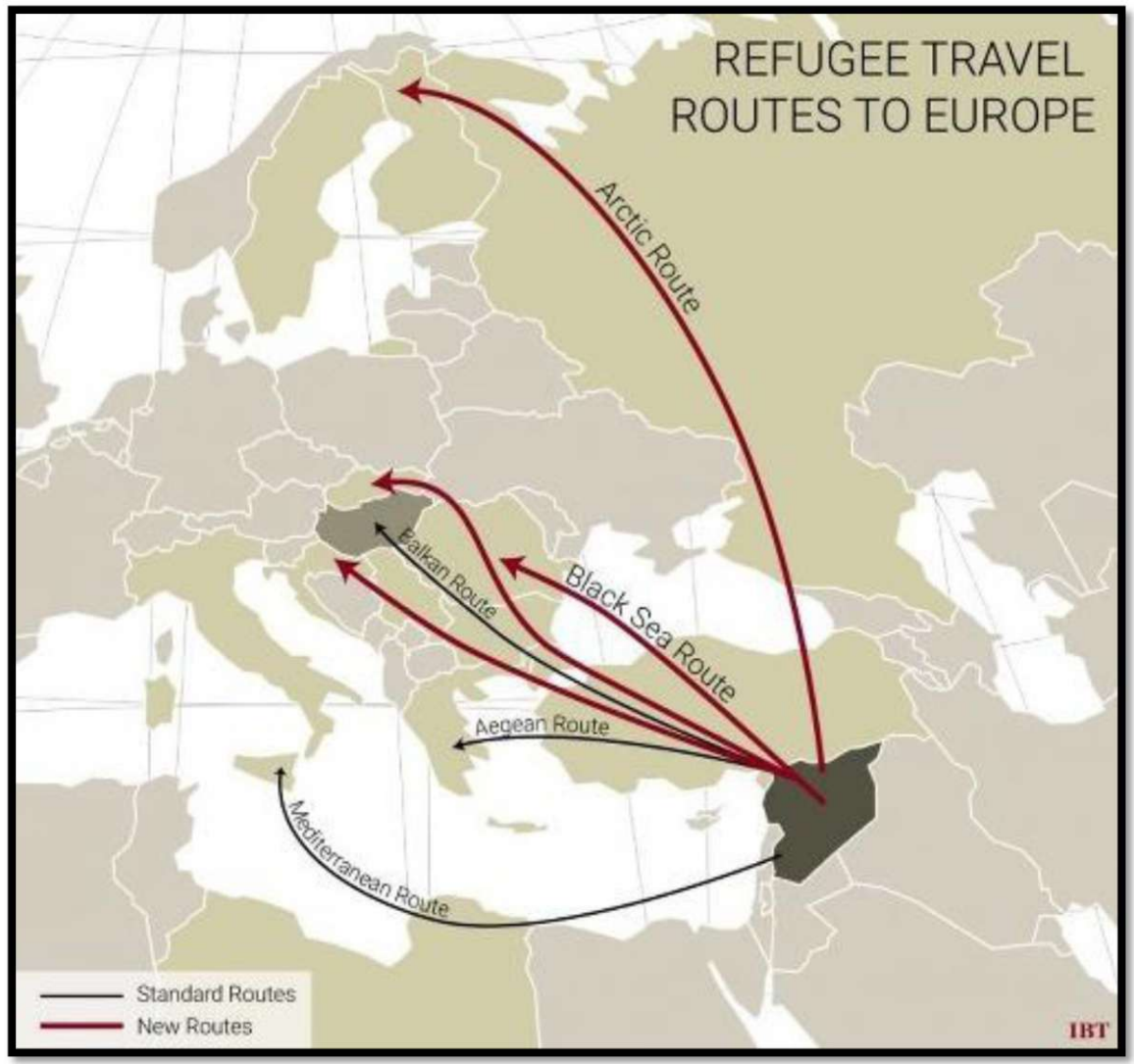

Figure 2. New refugee routes

Source: (Štatistiky MV SR)

internal order due to the flow of refugees. In 2014170000 refugees sailed over the Mediterraean Sea to Italy, in 2015 the number increased by $10 \%$.

Most of the refugees came to Italy from Libya as a result of the chaotic situation there, which means that human traffickers can act without any fear. Many refugees, however, did not survive the journey over the Mediterranean Sea (the number is estimated at tens of thousands). Since this route also fits murderers, the relationship between irregular migration and terrorism is considered by scholars around the world (Light, Thomas, 2021; Križovský, Kavečanská, Drotárová, 2020; Rožňák, Hrala, Drotárová, 2020; Lošonczi, Križovský, Reitšpís, 2018; Brodeur, Wright, 2019).

In 2014, about 65000 migrants entered Europe via the Balkan route, and 220,000 migrants sailed across the Mediterranean Sea. During the first half of the year, more than 140,000 migrants used the Balkan route to get to Greece, and about 90,000 migrants used the Mediterranean route to get to Italy. The total number of migrants who used the route through the Mediterranean Sea was represented by the following countries and percentages: 25\% Eritrea, 12\% Niger, $7 \%$ Somalia, 6\% Sudan and 5\% Syria.

The percentage and name of the countries from which migrants came who used the Balkan route in 2014 are as follows: 50\% Kosovo and Albania, $20 \%$ Syria, 15\% Afghanistan and 15\% other countries. The Balkan route, without migrants from Balkan, was taken by $61 \%$ of migrants from Syria and Iraque, $30 \%$ of migrants from Afganistan and 23\% from Pakistan. Most migrants go primarily to Germany and other German-speaking countries.

But why don't they use air transport? One seat on a human traffickers' ship costs 1,000 euros or more, while a flight from Lebanon to Great Britain costs about 400 euros, and from Egypt to Italy only about 320 euros. So, why do migrants prefer ships of human traffickers? First, the governments of the countries from which the migrants come are unwilling to stop migration, and second, according to the relevant guidelines, air and shipping companies that transport persons without personal and travel documents to any of the EU countries are obliged to transport such persons back to their home countries, and to do so at the companies' expense. However, the manual does not refer to persons with refugee status and shelter seekers. In any case, migrants who prefer the dangerous route through the Mediterranean Sea and the Balkan route do not have valid personal and travel documents, and, despite this, try to enter certain countries illegally illegal migration. 
A lot of people in Africa are dying of femine or they do not have enough money to pay human traffickers for being transported over the Mediteranean Sea to Europe; even if their lives are in danger, they can not emigrate in mass.

It is necessary to distinguish economic migrants from those really fleeing from a war and/or political persecuting, i.e. immigrants. People who have money and are able to buy a place on a ship from human traffickers seek to enter an economically developed country such as Germany, Sweden, Great Britain and similar countries; such people are considered economic migrants, illegally crossing the borders of European countries and with a clear goal. If people are fleeing from war, they tend to go to a safe place, i. e., the first country where there is no war and no danger of losing their lives or the lives of their relatives.

The decrease in the number of migrants following the Balkan route is due to an agreement between Turkey and the EU. The essence of the agreement is the reception and return of illegal migrants from Greece to Turkey.

\section{Political solutions as a source of increasing migration}

Although economic development efforts have always involved migration, these efforts, however, have always been a source of fear for the populations of such countries. The above-mentioned migration should not be confused with that aimed at expanding the EU, finding work, and getting to know a particular country/countries, especially in the case of the younger generation.

Migrations represent a threat not only when large numbers of people flee war and violence, but also when countries, mostly in Africa, have been trying for a long time to solve a climate problem or the problem of their political instability. Some countries, primarily developed countries in America and Europe, have supported in favour of their own economics both instability in particular functioning countries and migration to destabilize the EU representing an important player in the world history. Another problem is the perception of migration by some European countries, which are trying to follow their own ideas in solving the demographic problem. For example, Germany has faced a declining population in recent years. Germany has 6.4 children per 1,000 inhabitants, far fewer than comparable economically developed countries. However, this number is gradually decreasing, so Germany is applying an "open door" policy.

Changing demographics in an upward direction implies a higher pension. However, a very large number of migrants are needed to create an ideal retirement system. Germany experienced a baby boom in 1965 , and in 15 years this generation will need their own children to contribute to creating a pension for them. Since the children of the generation mentioned are usually few in number, a sufficient number of productive young people are needed. Germany sees its salvation in migrants, namely migrants from third countries. However, not every migrant is suitable and qualified to maintain the pension system. And there is a risk on the part of German society, whether it can handle and tolerate such a flow of migrants, mainly because of the existing risks and threats to internal order and security in the country.

In any case, migration forces consideration of legal or illegal ways to enter EU countries, i.e., without the necessary personal and travel documents and without checking the previous lives of migrants contributes to a precedent that threatens instability throughout the EU.

The following possibilities/arguments should be considered:

The first argument explains mass migration as solidarity on the part of Europe, like a voluntary exchange of migrants. This argument is often used by countries whose soldiers are in places that migrants leave.

The second arrgument is related to demographics, i.e., Europe is aging, and migrants should affect the growth momentum by making this or that country young.

The third argument is about global warming, i.e. the huge drought in Africa and the gradual movement of people into Europe.

\section{Terrorism as a possible result of emigrations}

\subsection{Historical development of terrorism}

Terrorism has accompanied the development of humanity since the struggle for power became a political matter. Depending on particular social conditions, terrorism has manifested itself in different ways in certain historical periods, whereas means of terrorism just like its various forms used to be changed.

Although the past of terrorism is very long, it is still part of human society and threatens the lives and laws of all people in the world. Terrorism is a challenge for all governments of the world, it sustains fear and antagonism and forces individual states to fight it, i.e., to invest energy and resources to solve it, while they should be used to solve more serious problems, such as poverty, inequality, environmental risks, etc. (Štatistiky MV SR).

\section{Antiquity}

Special literature argues that the first known terrorist actions were inspired by religious fanaticism. As early as in the 1st century $\mathrm{AD}$ there was a sect of the so-called Sicarii who attacked Roman legionaries and apostate Jews. 
In ancient Greece terrorism was frequently carried out by sovereigns, in wars of conquest, civil wars or in suppressing rebellions, in servile revolt and conquered tribes. At that time, violence against slaves, prisoners, and free citizens was not considered unusual. Terrorism practices took different forms, using different methods, which were characteristic of antiquity and lasted until the $11^{\text {th }}$ century.

\section{The Middle Ages}

In the Middle Ages, that is, around the $11^{\text {th }}$ century, a group of assassins was established in the Shia branch of Islam. Members of this group committed violent acts against Christian crusaders and some Sunni Muslims in Persia and Syria, characterized by asceticism, secrecy and the fact that they perceived the murders they did as evidence of true religious obedience. They believed their death as a result of fighting would bring them directly to Paradise.

Also, the territory of Europe experienced one of the most ruthless ways of terror, represented by the attacks of the military leader of the Mongols, namely Genghis Khan, and his group in the $13^{\text {th }}$ century. Ghengis Khan let massacre millions of inhabitants of the conquered places, even if they did not put up resistance to his group.

A specific form of terror in the Middle Ages is considered to be religious terror that was represented by the Inquisition of Jesuits and other church institutions against religious adversaries.

Practices of terrorism did not have any legal limitations and at first were considered to be common intimidating forms of reigning and gaining power. Later, using the practices was specified by law.

\section{The Human Era}

According to specialists, the present form of terrorism came into existance by declaration of the French Revolution, mainly at the time from 1793 to 1794 , i.e. after the deposition of the King, after his execution and establishment of a new power.

The first definition of terrorism followed the behavior of the revolutionaries themselves. A distinctive personality at the time was Maximilien de Robespierre, who under the slogan of defending the revolution and the republic (La Grande Terreur - The Great Terror) terrorized not only his real enemies, but later the population of France itself.

The literature often dates the beginning of the current form of terrorism to the second half of the $19^{\text {th }}$ century in Imperial Russia, the regime of which was the most undeveloped and most despotic. At that time, the first important political organization "Land and Liberty" was formed and encouraged a revolution in Russia. In 1874 the populist wing of the movement started the first series of such terrorist actions.

In the late $19^{\text {th }}$ cent. and the early $20^{\text {th }}$ cent. it is Balkan that that became the center of terrorism, where some of the worst events ever mentioned in history occurred, precisely as a result of political struggle.
The following dictatorial regimes and examples of state terrorism were developed in the 20th century: in Latin America it was the dictatorship of Chilean General Augusto Pinochet, in Argentina it was the government of the Argentine military junta, communist regimes notable for their brutality were represented by the Cambodian government of Pol Pot and the Khmer Rouge, and finally Nazism and Stalinism represented the highest level of terrorist state known to the $20^{\text {th }}$ century.

\section{Present Days}

From the last decades of the $20^{\text {th }}$ century to the present, the world has experienced 4 major terrorist waves representing a new/modern form of terrorism, namely the following cycles/waves:

The first wave of terrorism - has its beginning in the imperial Russia in 1880. Russian anarchists terrorized political figures through individual and systematic assassinations. The protagonists of the first wave of terrorism did not defend themselves against what they were called. Terrorist attacks by Russian anarchists contributed to the emergence of terrorist groups in other countries, namely Armenia, Poland, the Balkans and India.

The second wave of terrorism - is designated as "anti-colonial". It began in 1917 and lasted until 1965. The main motive of terrorist groups in this wave was the right of nations to self-determination. The assassinations of political leaders characteristic of the first wave have been partially replaced by murders directed against the police and law enforcement forces. Such actions were meant to provoke an inadequate and violent state response and thereby increase public support for the terrorists and damage the image of a particular colonial and repressive state. The terrorists began to realize how important it was to let their actions be known.

The third wave of terrorism - become an international phenomenon and expanded around the world. It began in 1968 and continued through the 1980s. This wave of terrorism was prominently associated with leftist movements whose activities were primarily directed against American and Western European imperialism. The terrorist organizations that fall into this period can be divided into three groups. The first group was represented by terrorist organisations fighting for national liberation, e.g. Palestinian terrorist organisations, the second group is represented by left-wing terrorist organisations in western Europe, i.e. IRA (Ireland), RAF (Germany), FRAP, GRAPO and ETA (Spain). The third group was represented by right-wing extremist terrorist groups working mainly in Latin America (Tupamaros in Uruguay, Montoneros in Argentina).

Third-wave terrorism became important ideologically and internationally, which meant that terrorist organizations began cooperating with foreign 
organizations and sometimes conducted actions outside their territory.

The fourth wave of terrorism - which began in 1979. During this period there were significant changes in the structure of world forces. The fourth wave terrorism manifests itself mainly in the depolarization of power, American hegemony and globalization, ethnic and religious conflict, regional instability, and civil wars. This wave of terrorism also means an increase in terrorist organizations based on Islamic fundamentalism and the use of new elements of terrorism, namely weapons of mass destruction.

The present form of terrorism includes not only new terrorist groups, but also organisations having been created in the third wave.

Modern terrorism has more forms, which manifests itself in cycles/waves, while individual cycles/waves refer to many committed terrorist acts. In any case, one cannot deny the historical diversity of manifestations of terrorism.

\subsection{Terrorism in the $21^{\text {th }}$ century}

The UN report states that the risks of terrorism in the $21^{\text {st }}$ century are very high and relevant. Many terrorist groups in this century operate on the principle of autonomous cells. Cells prepare their actions and terrorist attacks independently of the center. Each cell is obliged to work independently and not make contacts with the other cells, that is why to get into the cells and prevent their activity will present a serious problem in the furure.

\subsection{Reasons of origins and spreading the terrorism}

The majority of sociologists argue that all human actions and events are complex. The same is true for terrorist actions and campaigns. Therefore, explaining the causes of terrorism is a complicated and neverending task (Mesároš, 2018).

For the purposes of this paper, it can be argued that the causes of terrorism cannot be precisely defined because the decisions of individuals and groups to join terrorist activities are the result of many events, not all of which are equally important. Though the exact chain of reasons of particular terrorist attacks can not be determined with mathematical precision, familiarizing with the reasons of origins and spreading the terrorism necessitates researching the phenomenon from several viewpoints such as:

a) General-sociological viewpoint: is any violence or threat as a means to gain advantages or political respect. Individuals or groups undertake terrorist actions to enrich themselves and gain political influence.

b) Technical viewpoint: represents the high level of development of science and technology, as well as differences in the living standards of a part of the human population, while all this allows terrorists to easily obtain more destructive means to intimidate and attack the most vulnerable and well-protected targets.

c) Politological viewpoint: according to this view, terrorists are not only lone madmen, but they are often members of a strictly and secretly organized group, absolutely believing in the rightness of their actions.

d) Effectivity viewpoint: many terrorist actions forced different societies or world powers to act. They have taken actions that have resulted not only in stopping certain processes, but also in changing political power and the political map of the world (Mesároš, Lošonczi, 2019).

\section{Conclusion}

Migrations from the African continent and South America have something in common. Although it may seem wrong, migrations are driven by money. In any case, the aim of this article is not a political solution, but a gradual examination of the individual phases of migration from 2014 to 2020 .

After world pandemics, EU countries will begin to recover from economic problems, and migrants will gain new strength because they will already have information about how to obtain shelter benefits in individual countries. The populism of governments in favor of accommodating migrants will certainly surprise many political parties and show a pragmatic motive for migration. Is it unsuitable to say, as stated above, not all migrants are the same? They primarily choose economically developed countries, so the happiness of post-socialist countries is that they are not among the dream countries of economic migrants.

If it is confirmed that the sole purpose of Brexit was to regulate migration, it will become clear to everyone that the problem addressed in this document should be a priority for every EU country. There are many studies indicating that even coordinated economic assistance to individual countries in Africa is not a good form of solution. On the contrary, in specific African countries that receive financial support, it generates corruption and loss of money in favor of the government of the African continent.

There is one rule that will always be true, and that is that easy money will wean the native population off their work habits, and subsequently whatever they get without work in their home country they can get in any other EU country.

\section{Anknowlegements}

The article was created within the scientific project supported by the Ministry of Interior of the Slovak Republic called Creating and testing presentations of projects preventing illegal criminality. 


\section{References:}

Mesároš, M., \& Lošonczi, P. (2019). Migrácie v kontexte princípov terorizmu. Košice: Vydavatel' VŠBM v KE, 372 s. ISBN: 978-80-8185-035-5

Mesároš, M. (2011). Teória bezpečnosti. Košice: Multiprint s.r.o, 96 strán. ISBN: 978-80-89282-61-6

Mesároš, M. (2012). Ochrana osôb a majetku v kontexte ochrany ludských práv a chránených záujmov. Bratislava: SAV, 399 s. ISBN: 978-80-224-1240-7

Mesároš, M. (2018). Bezpečnostný optimizmus ako dôsledok nárastu terorizmu vo svete. Wyzsza szkola menedzerska w Warszawie, DBA thesis, $68 \mathrm{~s}$.

Statistiky MV SR (Statistics of the Ministry of Interior of the Slovak Republic)

Doina Popescu Ljungholm (2014). Preventing Illegal Migration in Romania. In: Procedia - Social and Behavioral Sciences, v. 149, p. 741-745. DOI: https://doi.org/10.1016/j.sbspro.2014.08.302

Mesároš, M. (2010). Bezpečnost', bezpečnostná veda a vzdelávanie v procese globalizácie. Košice: Multiprint s.r.o, 165 s. ISBN: 978-80-89282-45-C

Mesároš, M. (2018). Migrácie ako dôsledok politických a globalizačných riešení v kontexte princípov terorizmu. IPE MANAGEMENT SCHOOL - PARIS, Francúzsko, MSc thesis, $93 \mathrm{~s}$.

Light, M., \& Thomas, J. (2021). Undocumented immigration and terrorism: Is there a connection? In: Social Science Research, č. 94. DOI: https://doi.org/10.1016/j.ssresearch.2020.102512

Križovský, S., Kavečanská, A., \& Drotárová, J. (2020). Criminal Aspects of Illegal Migration. In: Security Dimensions: International and National Studies. Krakow, č. 33, s. 74-83.

Rožňák, P., Hrala, M., \& Drotárová, J. (2020). Mobile Einheit der Fremdenpolizei gegen illegale Migration in der Tschechischen Republik. In: Kriminalistik - Unabhängige Zeitschrift für die gesamte kriminalistische issenschaft und Praxis, vol. 74, no. 10, pp. 610-615.

Lošonczi, P., Križovský, S., \& Reitšpís, J. (2018). Current state and trends in the area of crime prevention. In: Proceedings of the third International workshop SECULIN, pp. 40-50.

Brodeur, A., \& Wright, T. (2019). Terrorism, immigration and asylum approval. In: Journal of Economic Behavior \& Organization, č. 168, s. 119-131. DOI: https://doi.org/10.1016/j.jebo.2019.10.002

Ústava SR, siedme vydanie, 1.5.2006 (Constitution of the Slovak Republic, the $7^{\text {th }}$ edition, 1.5.2006). 